\title{
Water and soil management for Drought Rice
}

\author{
Gehan, G. Abdel-Ghany and Zaky, M.H. \\ Desert research center, mataria, cairo, egypt
}

\begin{abstract}
Rice is an economically important and widely consumed cereal that achieves high yields under submerged condition. Moreover, due to degradation in physical properties of calcareous soils it is difficult to apply flood irrigation for sowing rice crop. So, the soil and water management is favorites. Whether, Draught rice with different levels of organic manure and water depletion used to achieve this target. The obtained results revealed that increasing organic addition (sheep dung) increased soil heat capacity and air permeability by $23.7 \%$ and $65 \%$ respectively, and decreased soil impedance by $21 \%$. Whilst, increasing moisture depletion raised soil impedance and air permeability by 2.5 and $6.8 \%$ respectively while the feeble effect was for heat capacity $(0.05 \%)$. When the two factors coupled together gave the major effects on previous properties. Also, roots weight increased by increasing soil heat capacity and air permeability and by decreasing soil impedance. Moreover, improving root growth and soil organic matter resulted in increasing rice cereal and straw yield while moisture depletion show a negative significant relation with cereal and negative non significant relation with straw, but when coupled with other factors it show a highly significant relation. Water consumption increase by increasing plant livetime and moisture depletion by $144 \%\left(181.27 \mathrm{~m}^{3}\right)$ and $1.5 \%\left(53.38 \mathrm{~m}^{3}\right)$ respectively. While, increasing roots weight and organic addition resulted in decreased water consumption by $5.3 \%\left(189.8 \mathrm{~m}^{3}\right)$ and $3.95 \%\left(140.4 \mathrm{~m}^{3}\right)$. Finally, by increasing organic additions and roots weight increased both cereal and straw water use efficiency by (21, $23 \%)$ and $(35,36 \%)$ respectively, While it decreased to $(9.4 \%)$ and $5.6 \%$ as increasing of moisture depletion.
\end{abstract}

Key wards: Soil management, water management, soil impedance and water use efficiency.

\section{INTRODUCTION}

Rice is necessary to the lives of billions of people around the world. It is the staple food for 2.5 billion People. About half the total world rice area is rainfed, where drought is major production constraint KANBAR et al (2009). Calcareous soil management purpose for improving its properties, to save it from degradation and increase productivity. Therefore, this study aim to economic the suitable condition of both soil and water to rice growth. Choosing draught rice is favorable for calcareous soils under draught conditions. Calcareous soil problems defined as raising of $\mathrm{pH}$ value, phosphate and ferrous compound sedimentation, active calcium carbonates occurrence and weak physical properties like penetrability, hydraulic conductivity and low thermal parameters Baver et al., (1976). In addition, physical problems, such as formation of surface crusts which affects directly on soil heat, roots respiration, water movement and soil impedance to plant roots growth Russell, (1989).

It is obvious that any phenomenon needs some energy to accomplish, which differs due to the nature of this phenomenon. So, increasing the soil heat capacity is simply reflecting the storing ability of soil for heat as calories. For example, when soil heat capacity change with $0.10 \mathrm{Cal} / \mathrm{g}$ (from 0.2 to 0.3 ) that is mean increasing of heat storage from 200 to 300 mega calories per feddan (for $20 \mathrm{~cm}$ soil depth). Addition of organic matter to soil not only increase soil heat content but also decreases soil thermal conductivity where the average of thermal conductivity of organic matter is $0.6 \mathrm{mCal} \mathrm{cm}-1 \mathrm{sec}^{-1}$

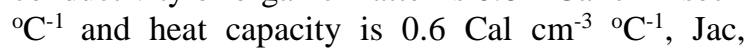

(1995). Nidal and Randall (2000) found that addition of peat moss decreased thermal conductivity for clay loam soil due to increase of soil organic matter content. Awadalla et al. (2001) mentioned that organic additions as compost by rates of $0,1,2$, and $4 \%$ to calcareous and sandy soils increased soil heat capacity. In general, soil moisture plays a double role where it instantly increases the heat capacity of soil depending on the heat capacity of water which is equal to five times greater than that of soil and the second role is the water movement either by mass flow or by diffusion Richards et al., (1952). Whatever, the inverse effect was obtained by Amal (1999) where she found that there was insignificant relation between heat capacity and moisture retention.

There are many terms used to express soil mechanical properties. One of These terms is soil impedance $\left(\mathrm{kg} / \mathrm{cm}^{2}\right)$ which conceder an expression for the soil resistance to mechanical force has been determined after rice harvesting. The fundamental goal of the current study is to investigate the favorable effect of the applied treatments; e.g. organic manure and water regime on soil mechanical properties. Concerning organic fertilizer, El- Hadidi et al. (2002) found that using gypsum farmyard manure and sand decreased penetration resistance and the best result was found with gypsum applied at 2.5 ton /fed. under cowpea and potato crops. Also, crop management coupled with annual manure application improved soil strength from 21 to $27 \%$ greater than control, Achmad et al., (2003). Meantime, Soane (1990) and Wagieh (2002) studied the effect of moisture 
depletion rates, i.e. 50 and $70 \%$ on penetration resistance of calcareous soil and found that decreasing depletion rate increased the penetrability.

Soil respiration depends on soil temperature, the availability of organic matter for oxidation, the composition of soil air and the volume of air filled pores. In addition, compaction increase bulk density and decrease the amount of pore space in a soil john and wayne (1992). Generally, addition of organic residues improves soil permeability. This finding is well agreed with those obtained by Daniel et al. (2003) who evaluated the emission of soil $\mathrm{CO}_{2}$, $\mathrm{N}_{2} \mathrm{O}, \mathrm{CH}_{4}$ and soil carbon and $\mathrm{N}$ indicators for four years after manure and compost application, they declared that the emission of $\mathrm{CO}_{2}$ were similar between control and other treatments. Also, fluxes of $\mathrm{CH}_{4}-\mathrm{C}$ and $\mathrm{N}_{2} \mathrm{O}-\mathrm{N}$ were nearly zero. Hiroko and Haruo (2003) investigate two types of manure i.e. poultry manure (PM) and swine manure (SM) and chemical fertilizers (urea) applied to soil, they found that fluxes from PM, SW, and urea for $\mathrm{NO}_{2}$ were $184,61.3$ and $44.8 \mathrm{Mg} \mathrm{N} \mathrm{m}^{-2}$, respectively. Soil moisture influence the soil air permeability in this context, Akinremi et al. (1999) studied the effect of soil temperature and moisture on soil respiration in barley and fallow ranged from a low of $1.6 \mathrm{~g} \mathrm{CO}_{2} \mathrm{~m}^{-}$ ${ }^{2} \mathrm{~d}^{-1}$ on dry day to a high of $8.3 \mathrm{~g} \mathrm{CO}_{2} \mathrm{~m}^{-2} \mathrm{~d}^{-1}$ on a wet day while the corresponding values for barely where 3.3 and $18.5 \mathrm{CO}_{2} \mathrm{~m}^{-2} \mathrm{~d}^{-1}$, respectively. AdvientoBrobe et al. (2006) declared that $\mathrm{N}_{2} \mathrm{O}$ emission at $60 \%$ of water-filled pore space (WFPS) was decreased from $2 \mathrm{mgm}^{-2}$ to $0.862 \mathrm{mgm}^{-2}$ while at $90 \%$ WFPS, $\mathrm{N}_{2} \mathrm{O}$ emission was 2 to 40 times greater than that at $60 \%$ WFPS.

High salt-stress generally leads to growth arrest and even plant death Munns and Tester (2008). Also; alkali stresses clearly inhibited rice growth, especially root growth Wang, (2011)

Drought stress in rice affects the crop in different ways Drought stress is considered to be a loss of water, which leads to stomatal closure and limitation of gas exchange. Drought stress is characterized by reduction of water content, diminished leaf water potential, turgor pressure, stomatal activity and decreasement in cell enlargement and growth. Severe water stress may result in the arrest of photosynthesis, disturbance in metabolism and finally the death of plant Jaleel, et $a l$. , (2008c). It reduces plant growth by affecting various physiological and biochemical processes, such as photosynthesis, respiration, translocation, ion uptake, carbohydrates, nutrient metabolism and growth promoters Farooq, et al., and (2008). Water stress is a limiting factor in agriculture production by preventing a crop from reaching the genetically determined theoretical maximum yield Begg and Turner, (1976). Swain, et al., (2010) evaluated eighteen rice genotypes and they found the reduction in panicle number $(72 \%)$ and grain yield (12\%). Singh, et al., (2010) evaluated the six generations (P1, P2, B1, B2, F1 and F2) of six crosses of rice under drought and irrigated conditions. They observed the reduction in several characters including grain yield under drought condition. They found thet plant height under well irrigated condition was $107.31 \mathrm{~cm}$ while it was only $92.00 \mathrm{~cm}$ average mean recorded for this character under drought condition. Mohd et al, (2015) investigated the effect of four treatments, T1: flooding at $5 \mathrm{~cm}$ depth, T2: flooding at $1-3 \mathrm{~cm}$ depth, T3: saturated to $1 \mathrm{~cm}$ flooding, and T4: alternative wet and dry (AWD) rice yield and water use efficiency and they found that Treatment T3 saved $45 \%$ of water use in $\mathrm{T} 1$ treatment and showed higher water use efficiency (WUE) but produced rice yield similar to $\mathrm{T} 1$ and $\mathrm{T} 2$ treatments. The main target of this study is to improve calcareous soils properties out of adding farmyard manure (sheep dung) and water regime to achieve the best production for draught rice and enhance the water use efficiency.

\section{MATERIAL AND METHODS}

A field experiment was carried out in split design in which the main plot was represented by three composted sheep dung application rates, i.e. 0 , 1 and $2 \%$ on weight basis. Sub-main plots were represented by two levels of soil moisture depletion i.e 30 and $50 \%$ with three replicates for each treatment. Thus, the experimental design is as follow: 3(application rates of sheep dung) $\mathrm{x} 2$ (irrigation water depletion) $\mathrm{x} 3$ (replicates) $=18$ plots.

After preparation plots were leveled and sown by draught rice (Orabi4) at 20 th April 2018. At harvesting time, soil penetration resistance was measured as $\mathrm{Kg} / \mathrm{cm}^{2}$ with penetrometer apparatus (SR-2 type Dik 5500). The soil heat capacity was measured using copper calorimeter method described by partington (1954). Soil air permeability measured according to Richard (1954). Organic matter (O.M) was determined as well as organic carbon (O.C) according to Jackson (1958) where, O.M \% = O.C \%. 1.72. The electrical conductivity (EC) was determined using 4075 Conductivity TDS meter described by Jackson (1958. The PH values of soil solution (1:5) were determined by $3010 \mathrm{P}^{\mathrm{H}}$ meter according to Black, et al., (1965). The initial physical and chemical properties of wadi surd soil, organic manure and irrigation water are shown in table (1).

\section{Water consumptive use:}

Soil moisture content determined at 3 depths; 020, 20-40 and 40-60 cm. 
Table 1: Physical and chemical properties of initial soil, organic manure and irrigation water.

\begin{tabular}{|c|c|c|c|c|c|c|c|c|c|c|c|}
\hline \multirow{3}{*}{$\begin{array}{l}\text { Physical } \\
\text { properties }\end{array}$} & \multicolumn{8}{|c|}{ Particle size distribution } & \multirow{2}{*}{$\begin{array}{c}\text { Impedance } \\
\mathrm{kg} / \mathrm{cm}^{2}\end{array}$} & \multirow{2}{*}{$\begin{array}{c}\text { air } \\
\text { permeability } \\
\mathrm{cm}^{2} \\
\end{array}$} & \multirow{2}{*}{$\begin{array}{c}\text { Heat } \\
\text { capacity } \\
\text { cal } / \mathrm{g} \\
\end{array}$} \\
\hline & \multicolumn{2}{|c|}{ Sand } & Silt & \multicolumn{2}{|c|}{ Clay } & \multicolumn{3}{|c|}{ Texture class } & & & \\
\hline & \multicolumn{2}{|c|}{85} & 7.02 & \multicolumn{2}{|c|}{7.98} & \multicolumn{3}{|c|}{ L.S } & 21.8 & $4.2 \mathrm{E}-05$ & 0.1922 \\
\hline \multirow{2}{*}{$\begin{array}{l}\text { Chemical } \\
\text { properties }\end{array}$} & \multicolumn{2}{|c|}{$\mathrm{CaCO}_{3 \%}$} & $\mathrm{ECdS} / \mathrm{m}$ & \multicolumn{2}{|c|}{$\mathrm{pH}$} & \multicolumn{3}{|c|}{ CEC } & \multicolumn{3}{|c|}{ OM\% } \\
\hline & \multicolumn{2}{|c|}{51.9} & 10.4 & \multicolumn{2}{|c|}{7.9} & \multicolumn{3}{|c|}{2.8} & \multicolumn{3}{|c|}{0.25} \\
\hline \multirow{2}{*}{$\begin{array}{l}\text { Sheep } \\
\text { dung }\end{array}$} & \multicolumn{2}{|c|}{$\mathrm{C} \%$} & $\mathrm{~N} \%$ & \multicolumn{2}{|c|}{$\mathrm{C}: \mathrm{N}$} & \multicolumn{3}{|c|}{$\mathrm{P} \mathrm{mmol} / \mathrm{l}$} & \multicolumn{2}{|c|}{ Heat capacity cal/g } & OM\% \\
\hline & \multicolumn{2}{|c|}{23.5} & 1.9 & \multicolumn{2}{|c|}{12.1} & \multicolumn{2}{|c|}{0.56} & 3.1 & \multicolumn{2}{|c|}{$0.4125 \mathrm{~s}$} & 40.42 \\
\hline \multirow{3}{*}{$\begin{array}{l}\text { Irrigation } \\
\text { water }\end{array}$} & \multicolumn{8}{|c|}{ Soluble cations and anion $\mathrm{m} \mathrm{mol} / \mathrm{l}$} & SAR & $\mathrm{ECdS} / \mathrm{m}$ & $\mathrm{pH}$ \\
\hline & $\mathrm{Na}$ & $\mathrm{Ca}$ & $\mathrm{Mg}$ & $\mathrm{K}$ & $\mathrm{Cl}$ & $\mathrm{CO}_{3}$ & $\mathrm{HCO}_{3}$ & $\mathrm{SO}_{4}$ & & & \\
\hline & 45.6 & 12.41 & 2.46 & 0.44 & 55.8 & - & 1.9 & 9.5 & 9.6 & 7.24 & 7.55 \\
\hline
\end{tabular}

The actual evapotranspiration (ETa) for each stage and the total season were determined, crop coefficient was calculated for every growth stage according to Allen et al, (1998), Crop Water Use Efficiency (WUE), $\mathrm{kg} / \mathrm{m}^{3}$ was calculated by dividing the crop yield by the amount of seasonal evapotranspiration Giriappa, (1983). NPK mixture fertilizer was added once as activate portion at tillering stage by the rate of $50 \mathrm{~kg} / \mathrm{fed}$. Yield components as Yield of Grain and Steam by kg/fed.

\section{RESULTS AND DISCUSSION}

Effect of studying factors on some soil physical properties.

\section{Heat capacity:}

Soil heat capacity (as calories per gram of soil) is considered as one of the important parameters for cultivated lands. Because of, its affecting on soil respiration, decomposition of organic matter, seed germination, micro organisms activity and nutrients availability. The main target of this study is to enhancing soil heat capacity by applying organic manure and water depletion, whatever, table (2) point out that soil heat capacity increase by $23.7 \%$ as organic manure addition increase, while the feebleness effect shown by moisture depletion $(0.05 \%)$. Meantime, the interaction of the two factors led to increase heat capacity by $24 \%$. The weakness effect of moisture depletion due to that during estimate heat capacity all samples dried on nearly $100^{\circ} \mathrm{C}$ for 24 hour so, all samples moisture were removed and the value of heat capacity refer only to soil particles and their organic matter. This result agree with Awadalla et al. (2001) and amal (1999).

Table (3) of ANOVA statistical declares that there are significant differences between values of heat capacity for all treatments. Also, the complementally effect of the two factors shown by fig (1) which assure that the important of the effect of mixing factors on increasing heat capacity. The simple and multiple correlations were: 0.961***, $0.01 \mathrm{NS}$ and $\mathrm{R}=0.971 * * *$ and the simple regression is,:

$\mathrm{SHC}(\mathrm{cal} / \mathrm{g})=0.19+0.02 \mathrm{OM} \%-6 \mathrm{E}-06$ Өd $\%$

Where, SHC is soil heat capacity, OM\% is organic matter and $\Theta \mathrm{d} \%$ is moisture depletion Soil impedance:

Soil impedance $\left(\mathrm{kg} / \mathrm{cm}^{2)}\right.$ as an expression for the soil resistance to mechanical force has been determined at the end of each season. Table (2) and fig (1) show that soil impedance to penetration by used cone increase by $2.5 \%$ by increasing moisture depletion and decrease by $21,24 \%$ for organic manure and inter action respectively.

Therefore, Statistical analysis of ANOVA conducted to study the effect of the antecede used application as well as their interaction. Table (4) declares that all factors and their interactions resulted in significant different between mean values of soil impedance.

Table 2: Some soil physical properties and roots weight as affected by study factors.

\begin{tabular}{ccccc}
\hline $\begin{array}{c}\text { sheep } \\
\text { dung \% }\end{array}$ & $\begin{array}{c}\text { Moisture } \\
\text { depletion \% }\end{array}$ & $\begin{array}{c}\text { Heat capacity } \\
\mathbf{C a l} / \mathbf{g}\end{array}$ & $\begin{array}{c}\text { Air permeability } \\
\mathbf{c m}^{\mathbf{2}}\end{array}$ & $\begin{array}{c}\text { Soil impedance } \\
\mathbf{~ k g c m}^{\mathbf{2}}\end{array}$ \\
\cline { 2 - 5 } 0 & 30 & 0.1921 & $4.4 \mathrm{E}-05$ & 20.90 \\
\hline \multirow{2}{*}{1} & 50 & 0.1920 & $4.7 \mathrm{E}-05$ & 21.42 \\
\cline { 2 - 5 } & 30 & 0.2245 & $5.2 \mathrm{E}-05$ & 18.20 \\
\hline \multirow{2}{*}{2} & 50 & 0.2244 & $6.1 \mathrm{E}-05$ & 19.10 \\
\cline { 2 - 5 } & 30 & 0.2378 & $7.1 \mathrm{E}-05$ & 16.20 \\
\hline
\end{tabular}


Table 3: Three way ANOVA split plot analysis for soil heat capacity

\begin{tabular}{lccccc}
\hline \multicolumn{7}{c}{ Soil heat capacity } & & \\
\hline Source of variance & SS & DF & MS & F & P \\
\hline Main plot blocks & $-1.1 \mathrm{E}-016$ & 2 & $-5.5 \mathrm{E}-017$ & & $0.000 * * *$ \\
\hline Organic manure ( OM) $\%$ & 0.006 & 2 & 0.003 & $1.1 \mathrm{E}+14$ & \\
\hline Main plot error & $1.1 \mathrm{E}-06$ & 4 & $2.7 \mathrm{E}-017$ & & $0.000^{* * *}$ \\
\hline Moisture depletion( Od)\% & $8 \mathrm{E}-08$ & 1 & $8 \mathrm{E}-08$ & 4323455634 & $0.000^{* * *}$ \\
\hline Od $*$ OM & $1 \mathrm{E}-08$ & 2 & $5 \mathrm{E}-09$ & 270215979 & \\
\hline Error & $1.1 \mathrm{E}-016$ & 6 & $1.8 \mathrm{E}-017$ & & \\
\hline Total & 0.006 & 17 & & & \\
\hline
\end{tabular}
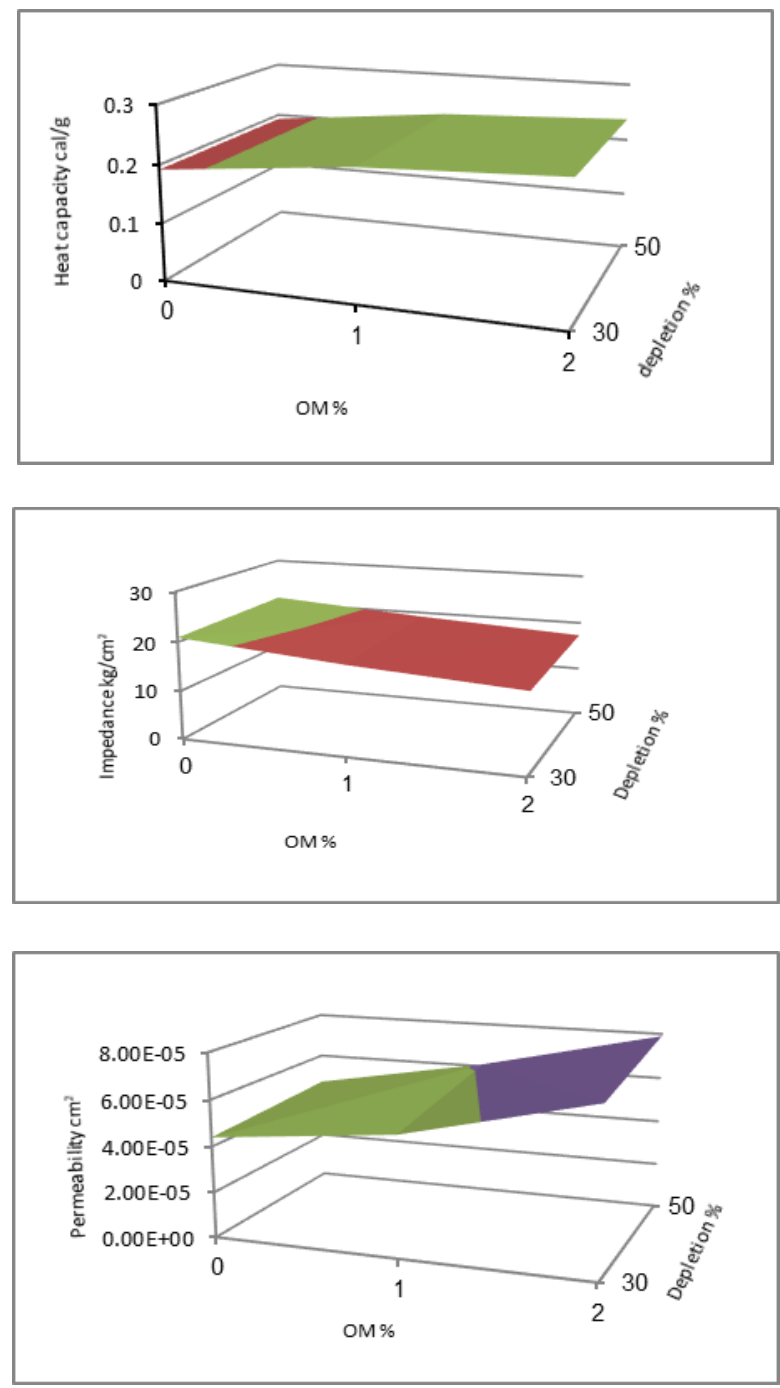

Fig 1: Some soil physical properties affected by studied factors inter action.

Table 4: Three way ANOVA split plot analysis for soil impedance

\begin{tabular}{lccccc}
\hline \multicolumn{7}{c}{ Soil impedance } & & \\
\hline Source of variance & SS & DF & MS & F & P \\
\hline Main plot blocks & 0.0560 & 2 & 0.028 & & $0.000^{* * *}$ \\
\hline Organic manure OM\% & 58.716 & 2 & 29.35 & 4879.4 & \\
\hline Main plot error & 0.0240 & 4 & 0.006 & & $0.000^{* * *}$ \\
\hline Moisture depletion ( $\mathrm{Ad}) \%$ & 3.175 & 1 & 3.175 & 190512 & $0.000^{* * *}$ \\
\hline Od $*$ OM & 0.2604 & 2 & 0.1302 & 7812 & \\
\hline Error & $1 \mathrm{E}-04$ & 6 & $1.6 \mathrm{E}-05$ & & \\
\hline Total & 62.23 & 17 & & & \\
\hline
\end{tabular}


Meantime, the simple and multiple correlations were: $\mathrm{r}=-0.968 * * *, \mathrm{r}=0.225 \mathrm{NS}$ and $\mathrm{R}=-0.978 * * *$. The multiple regression is as follow:

$\mathrm{S} \mathrm{I}\left(\mathrm{kg} / \mathrm{cm}^{2}\right)=19.37-2.2 \mathrm{OM} \%+0.04 \mathrm{\Theta d} \%$

Where, SI is soil impedance, OM is organic matter $\%$ and $\Theta \mathrm{d} \%$ is moisture depletion

Finally, the role of organic matter in improving soil penetrability refer to the resin products from organic matter decaying lubricate soil particle and make cone injection in soil is easy, also increasing moisture play the same role. These results are matching with the studies of Achmad et al., (2003) and Wagieh (2002).

\section{Air permeability:}

The decreased in soil air permeability values of calcareous soils is considered one of the problems which resulted from compaction. Moreover, Permeability of soil to air is one of the most important factors affecting gaseous exchange between soil and atmosphere this parameter depends on soil temperature, the availability of organic matter for oxidation and soil compaction. Table (2) and fig (1) declare that soil permeability to air increase by $65,6.8$ and $79 \%$ for organic manure, moisture depletion and interaction respectively. Meantime, the statistical analysis of ANOVA shown in table (5) declare that there are different significant between mean values of air permeability and the simple and multiple correlations are, $\mathrm{r}=$ $0.948 * * *, 0.262 \mathrm{NS}$ and $\mathrm{R}=0.984 * * *$ and the multiple regression is: $\mathrm{AP}\left(\mathrm{cm}^{2}\right)=3 \mathrm{E}-05+1.4 \mathrm{E}-05$ OM\%+3.3E-07 Өd\%.

Where, AP Air permeability, OM is organic matter and $\Theta d$ is moisture depletion
This result is agreed with those obtained by Daniel et al. (2003) and Adviento-Brobe et al. (2006).

\section{Root growth:}

There are many soil factors impact on plant roots growth, activity and interaction with soils, the degradation of these factors inhibits roots growth. In general, soil temperature, impedance and aeration impact directly on roots growth where, the minimum and optimal temperatures depend upon the plant species and are typically in the ranges of $0-12^{\circ} \mathrm{C}$ and $25-35^{\circ} \mathrm{C}$, respectively, while the maximum is almost always round $40-45^{\circ} \mathrm{C}$ also, soil with high strength may limit root growth because they exert more mechanical energy to root growth and/or restrict the supply of oxygen to roots. In addition, a part of the pore space must be gasfilled and allows the supply of $\mathrm{O}_{2}$ to roots to maintain respiration, and the removal of $\mathrm{CO}_{2}$ from the root zoon. These processes of gases exchange showed be fast enough then root growth is restricted, Peter (2006). Table (6) and fig (2) declare that increase soil heat capacity and air permeability resulted in increasing roots weight in the same time decreasing soil impedance increase roots weight. Whether, every $0.01 \mathrm{cal} / \mathrm{g}$ enhancing of heat capacity increase roots weight by $0.12 \mathrm{Ton} \mathrm{fed}^{-1}$, while, each of $1 \mathrm{~cm}^{2}$ rising led to increased roots weight by 0.14 Ton fed $^{-1}$. Contrary, every $1 \mathrm{~kg} \mathrm{~cm}^{-2}$ decreasing of soil impedance increase roots weight by 0.08 Ton fed $^{-1}$. Table (7) of ANOVA points out that all factors and their interaction have a significant differences between all treatments for root weight.

Table 5: Three way ANOVA split plot analysis for soil air permeability

\begin{tabular}{lccccc}
\hline \multicolumn{7}{c}{ Soil air permeability } & & P \\
\hline Source of variance & SS & DF & MS & F & \\
\hline Main plot blocks & $3.3 \mathrm{E}-13$ & 2 & $1.6 \mathrm{E}-13$ & & $0.000 * * *$ \\
\hline Organic manure OM\% & $2.6 \mathrm{E}-09$ & 2 & $1.3 \mathrm{E}-09$ & 8000.9 & \\
\hline Main plot error & $6.6 \mathrm{E}-13$ & 4 & $1.6 \mathrm{E}-13$ & & $0.000 * * *$ \\
\hline Moisture depletion $\Theta d \%$ & $2 \mathrm{E}-10$ & 1 & $2 \mathrm{E}-10$ & 1200 & $0.000^{* * *}$ \\
\hline Od $*$ OM & $3.1 \mathrm{E}-11$ & 2 & $1.5 \mathrm{E}-11$ & 93 & \\
\hline Error & $1 \mathrm{E}-12$ & 6 & $1.6 \mathrm{E}-13$ & & \\
\hline Total & $2.9 \mathrm{E}-09$ & 17 & & & \\
\hline
\end{tabular}

Table 6: Rice yield parameters.

\begin{tabular}{lcccc}
\hline organic & depletion & Cereal kg/fed. & Straw kg/fed. & $\begin{array}{c}\text { Root weight } \\
\text { (RW)Ton/fed. }\end{array}$ \\
\hline $0 \%$ & $30 \%$ & 1814.8 & 1903.9 & 0.39 \\
\cline { 2 - 4 } & $50 \%$ & 1789.9 & 1875.2 & 0.31 \\
\hline \multirow{2}{*}{$1 \%$} & $30 \%$ & 2067.2 & 1968.5 & 0.65 \\
\hline $2 \%$ & $50 \%$ & 1901.5 & 1996.8 & 0.52 \\
\cline { 2 - 4 } & $30 \%$ & 2301.6 & 2415.4 & 0.79 \\
\hline
\end{tabular}



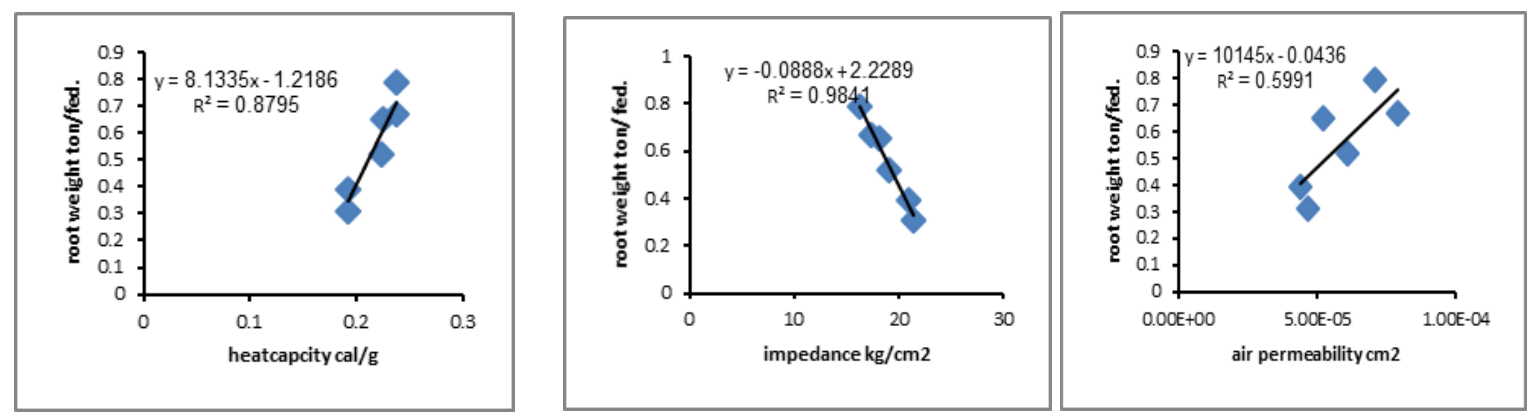

Fig 2: Root weight affected by some calcareous soil properties.

Table 7: Three way ANOVA split plot analysis for roots weight.

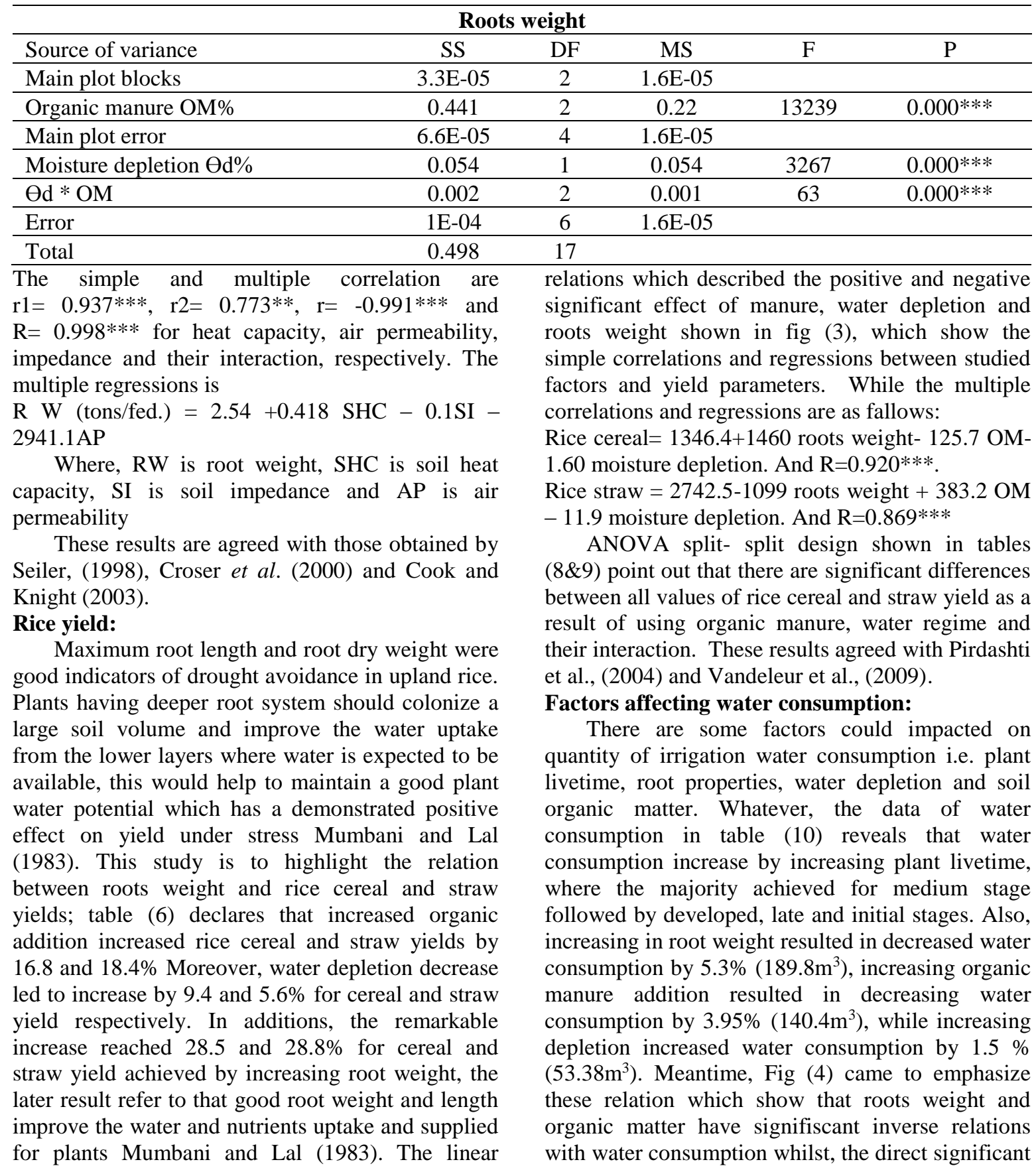


and no significant relations were for plant livetime and moisture depletion respectively. The simple correlation and regression showed previous figure, while the multiple regression and correlations were
$\mathrm{Y}=3399.1+85.6 \mathrm{x}_{1}-86.5 \mathrm{x}_{2}+3.1 \mathrm{x}_{3}$ where $\mathrm{Y}, \mathrm{x}_{1} \mathrm{x}_{2}$ and $\mathrm{X}_{3}$ are water consumption, roots weight, organic manure and depletion respectively.
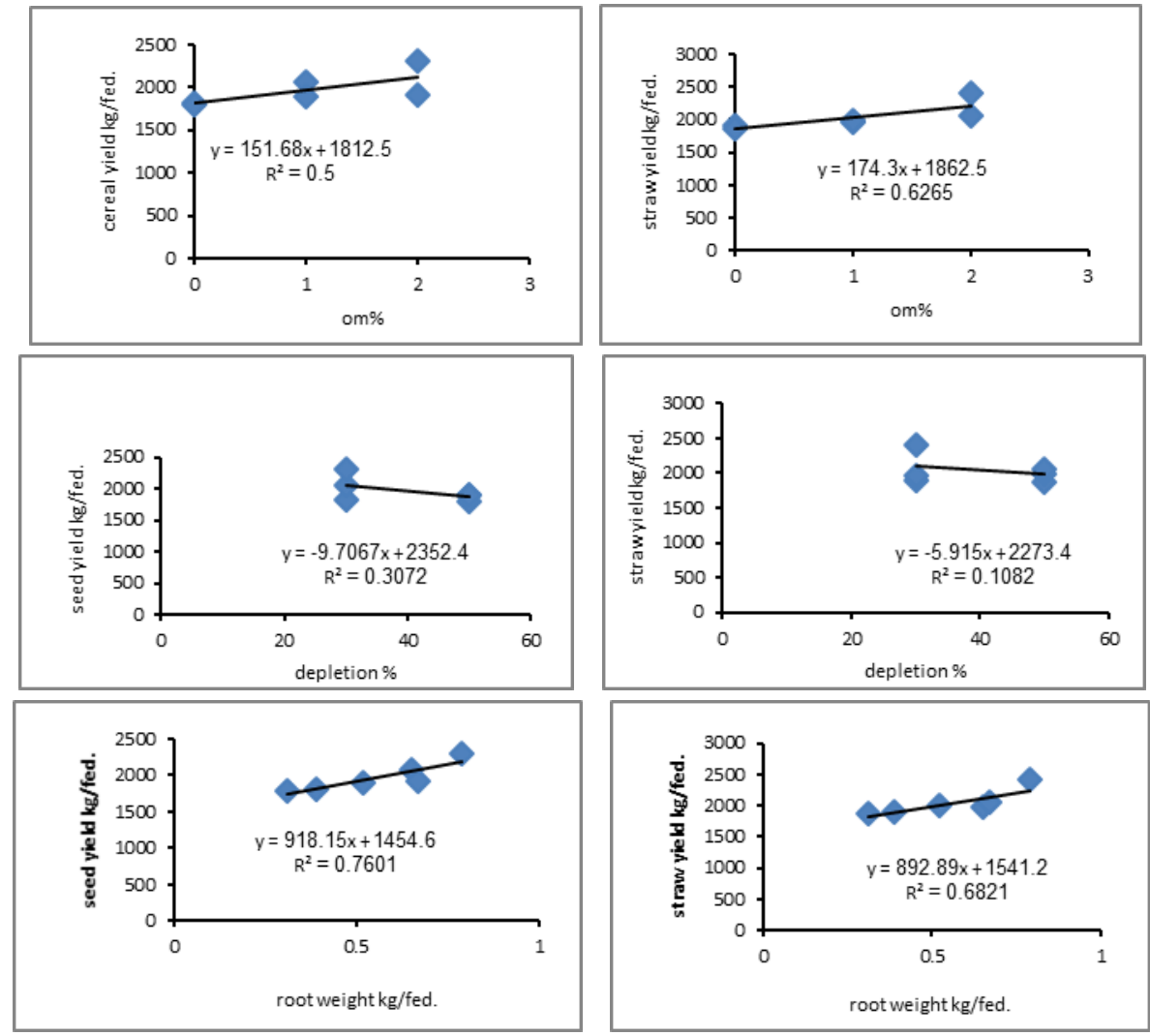

Fig 3: Rice cereal and straw yield affected by organic matter, water depletion and roots weight.

Table 8: Three way ANOVA split plot analysis for cereal yield.

\begin{tabular}{lccccc}
\hline \multicolumn{7}{c}{ Cereal yield } & & \\
\hline Source of variance & SS & DF & MS & F & P \\
\hline Main plot blocks & 0.003 & 2 & 0.001 & & $0.000 * * *$ \\
\hline Organic manure OM\% & 279742.09 & 2 & 139871.045 & 83922519.4 & \\
\hline Main plot error & 0.006 & 4 & 0.001 & & $0.000^{* * *}$ \\
\hline Moisture depletion $\Theta d \%$ & 169594.8 & 1 & 169594.8 & 101757025 & $0.000^{* * *}$ \\
\hline Od * OM & 102780.7 & 2 & 51390.3 & 30834248.4 & \\
\hline Error & 0.009 & 6 & 0.001 & & \\
\hline Total & 552117.7 & 17 & & & \\
\hline
\end{tabular}

Table 9: Three way ANOVA split plot analysis for straw yield

\begin{tabular}{lccccc}
\hline \multicolumn{7}{c}{ Straw yield } & & & \\
\hline Source of variance & SS & DF & MS & F & P \\
\hline Main plot blocks & $-1.49 \mathrm{E}-08$ & 2 & $-7.4 \mathrm{E}-09$ & & \\
\hline Organic manure OM\% & 390939.6 & 2 & 195469.82 & $5.2 \mathrm{E}+13$ & $0.000^{* * *}$ \\
\hline Main plot error & $1.49 \mathrm{E}-08$ & 4 & $3.7 \mathrm{E}-09$ & & \\
\hline Moisture depletion $\Theta d \%$ & 62977.005 & 1 & 62977.005 & $2.5 \mathrm{E}+13$ & $0.000^{* * *}$ \\
\hline Od $*$ OM & 127965.24 & 2 & 63982.62 & $2.57 \mathrm{E}+13$ & $0.000^{* * *}$ \\
\hline Error & $1.49 \mathrm{E}-08$ & 6 & $2.48 \mathrm{E}-09$ & & \\
\hline Total & 581881.8 & 17 & & & \\
\hline
\end{tabular}


Table 10: Actual water consumption and water use efficiency.

\begin{tabular}{cccccccccc}
\hline organic & depletion & int. & develop & mid & late & total & m3/f & $\begin{array}{c}\text { GRAIN } \\
\text { WUE }\end{array}$ & $\begin{array}{c}\text { STRAW } \\
\text { WUE }\end{array}$ \\
\hline \multirow{2}{*}{$0 \%$} & $30 \%$ & 127.62 & 210.61 & 309.01 & 192.5 & 839.74 & 3526.9 & 0.515 & 0.54 \\
\cline { 2 - 10 } & $50 \%$ & 131.15 & 215.12 & 312.4 & 194.2 & 852.87 & 3582.05 & 0.5 & 0.524 \\
\hline \multirow{2}{*}{$1 \%$} & $30 \%$ & 123.81 & 208.43 & 304.83 & 186.94 & 824.01 & 3460.84 & 0.597 & 0.569 \\
\hline \multirow{2}{*}{$2 \%$} & $50 \%$ & 125.92 & 212.94 & 309.27 & 189.2 & 837.33 & 3516.77 & 0.541 & 0.568 \\
\cline { 2 - 9 } & $30 \%$ & 120.93 & 204.11 & 300.13 & 181.85 & 807.02 & 3389.48 & 0.679 & 0.713 \\
\hline
\end{tabular}

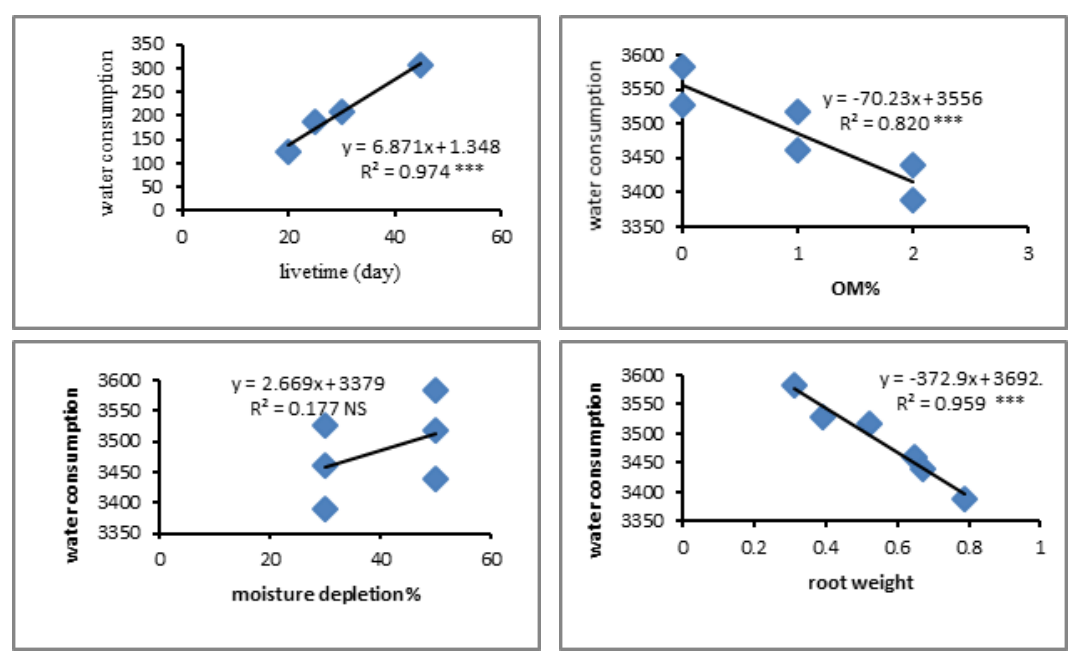

Fig 4: Water consumption affected by plant live time, organic addition, water depletion and root weight.

Also, Table (11) of ANOVA show that there are significant differences between all mean values of water consumption achieved by all treatments and their interaction. The aforementioned effects signify the increase of organic additions, roots weight led to the ability of moisture retentively and absorbed resulted to decreasing water consumption. In addition, long livetime and raising depletion increased water application as a result of increasing plant water consumption.

Water use efficiency (WUE):

Improving water use efficiency requires a development of satisfactory means to estimate crop water requirements or evapotranspiration (ETo). Water use efficiency cumulative study values in Table (10) point out that both cereal or straw water use efficiency increased by increasing organic additions and roots weight, this increase reached $(21,23 \%)$ and $(35,36 \%)$ respectively. while its decrease by $(10.9 \%)$ and $(7.2 \%)$ by increasing moisture depletion. The linear relations and simple correlation and regression in Fig (5) assure root weight and organic manure affect significantly on WUE of cereal and straw, whilst depletion shows significant relation with WUE of cereal and non significant with WUE of straw . These factors when coupled together showed a highly significant with WUE of cereal and straw $(\mathrm{R}=0.919 * * *$, $\mathrm{R}=0.900 * * *)$ respectively, and the multiple regression were;

$\mathrm{Y}_{1}=0.511+0.19 \mathrm{x}_{1}+0.017 \mathrm{x}_{2}-0.001 \mathrm{x}_{3}$ and

$\mathrm{Y}_{2}=0.8-0.32 \mathrm{x}_{1}+0.12 \mathrm{x}_{2}-0.003 \mathrm{x}_{3}$

Table 11: Three way ANOVA split plot analysis for water consumption.

\begin{tabular}{lccccc}
\hline \multicolumn{7}{c}{ Straw yield } & F & $\mathrm{P}$ \\
\hline Source of variance & $\mathrm{SS}$ & $\mathrm{DF}$ & $\mathrm{MS}$ & & \\
\hline Main plot blocks & 0.003 & 2 & 0.001 & $0.000^{* * *}$ \\
\hline Organic manure OM\% & 59274.5 & 2 & 29637.25 & 17782371.2 & \\
\hline Main plot error & 0.006 & 4 & 0.001 & & $0.000^{* * *}$ \\
\hline Moisture depletion $\Theta d \%$ & 12822.409 & 1 & 12822.409 & 7693453.2 & $0.000^{* * *}$ \\
\hline Od * OM & 42.44 & 2 & 21.22 & 12734.02 & \\
\hline Error & 0.009 & 6 & 0.001 & & \\
\hline Total & 72139.39 & 17 & & & \\
\hline
\end{tabular}



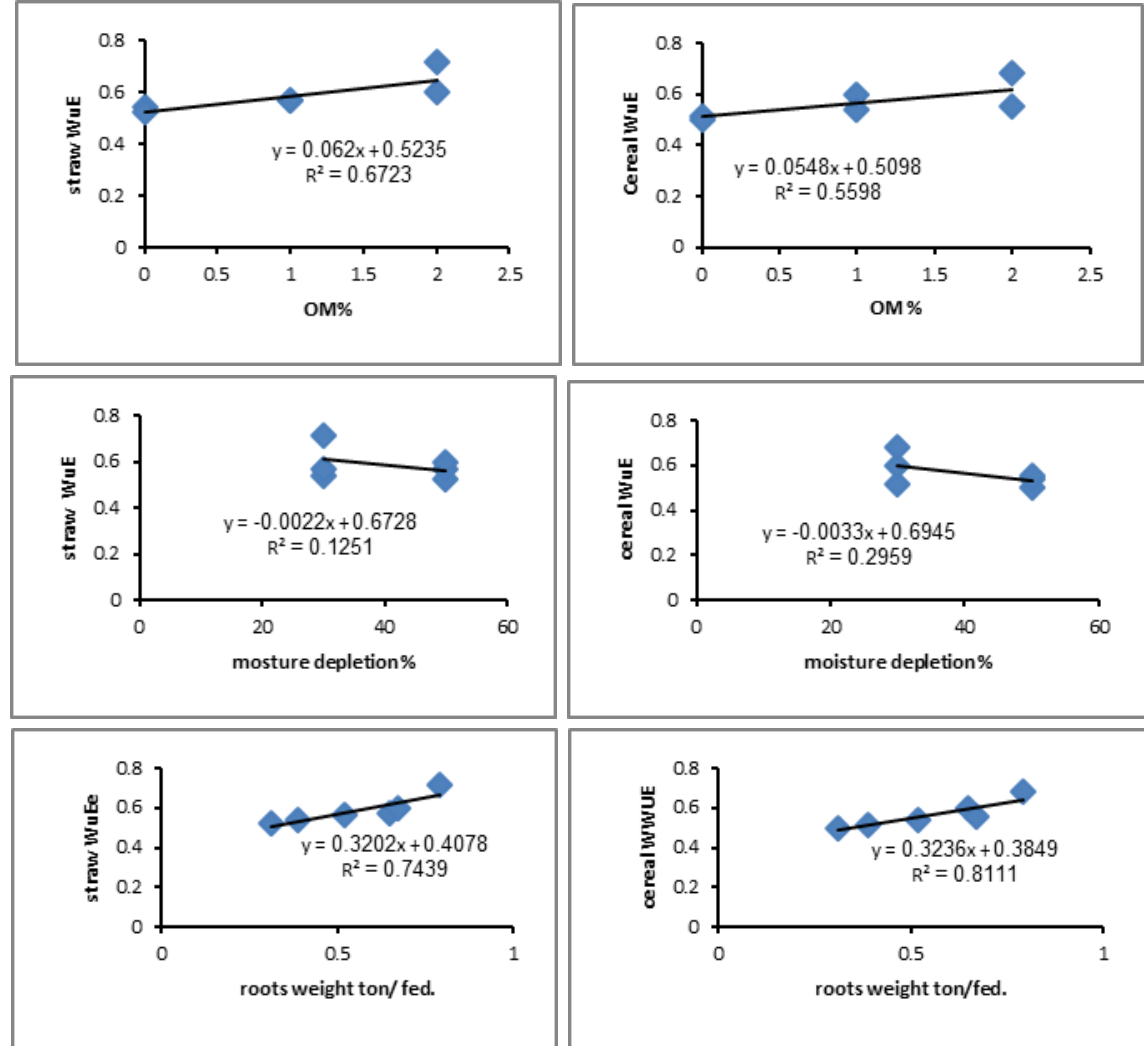

Fig 5: cereal and straw WUE affected by organic addition, water depletion and roots weight.

Where, $\mathrm{Y}_{1}, \mathrm{y}_{2}, \mathrm{x}_{1}, \mathrm{x}_{2}$ and $\mathrm{x}_{3}$ are cereal WUE, straw WUE, roots weight, organic manure and moisture depletion. There are significant differences between all values of cereal and straw WUE refer to sole study factors and their interaction tables (12\&13).
Raising soil organic matter increase soil moisture retention and decrease moisture strain upon plants. Moreover, increasing roots weight mean improve the water uptake from the lower layers where water is expected to be available.

Table 12: Three way ANOVA split plot analysis for cereal WUE.

\begin{tabular}{lccccc}
\hline \multicolumn{7}{c}{ Straw yield } & & & \\
\hline Source of variance & SS & DF & MS & F & P \\
\hline Main plot blocks & $8.3 \mathrm{E}-06$ & 2 & $4.1 \mathrm{E}-06$ & & \\
\hline Organic manure ( OM)\% & 0.035 & 2 & 0.017 & 4318.9 & $0.000^{* * *}$ \\
\hline Main plot error & $1.6 \mathrm{E}-05$ & 4 & $4.1 \mathrm{E}-06$ & & \\
\hline Moisture depletion ( Od)\% & 0.05 & 1 & 0.015 & 3759.48 & $0.000^{* * *}$ \\
\hline Od * OM & 0.009 & 2 & 0.004 & 1188.36 & $0.000^{* * *}$ \\
\hline Error & $2.5 \mathrm{E}-05$ & 6 & $4.1 \mathrm{E}-06$ & & \\
\hline Total & 0.061 & 17 & & & \\
\hline
\end{tabular}

Table 13: Three way ANOVA split plot analysis for straw WUE.

\begin{tabular}{lccccc}
\hline \multicolumn{7}{c}{ Straw yield } & & & \\
\hline Source of variance & SS & DF & MS & F & P \\
\hline Main plot blocks & $3.3 \mathrm{E}-05$ & 2 & $1.6 \mathrm{E}-05$ & & $0.000^{* * *}$ \\
\hline Organic manure ( OM) $\%$ & 0.048 & 2 & 0.024 & 1461.87 & \\
\hline Main plot error & $6.6 \mathrm{E}-05$ & 4 & $1.6 \mathrm{E}-05$ & & $0.000^{* * *}$ \\
\hline Moisture depletion( Od) \% & 0.008 & 1 & 0.008 & 514.83 & $0.000^{* * *}$ \\
\hline Od * OM & 0.011 & 2 & 0.005 & 338.97 & \\
\hline Error & $1 \mathrm{E}-04$ & 6 & $1.6 \mathrm{E}-05$ & & \\
\hline Total & 0.068 & 17 & & & \\
\hline
\end{tabular}




\section{CONCLUSION}

Rice is central to the lives of billions of people around the world. It is the staple food for 2.5 billion People. About half the total world rice area is rainfed, where drought is major Production constraint KANBAR et al (2009). Calcareous soil management purpose that improving its properties, saving it from degradation and making maximum use of it. Therefore, this study aim to economic the suitable condition of both soil and water to rice growth, choosing draught rice is favorable for calcareous soil under draught conditions. Based upon results, the following can be concluded:

The effects of the applied treatments which improve most of studied soil characters terminally affect positively the crop yield parameters.

This complementally effect sustained over the studied successive season of cultivation with draught rice crop which indicate durability of these treatments in face of environmental and climatologically conditions.

The obvious role of organic matter and irrigation water depletion in producing crops has been detected with yield parameters, in which organic application had the major role in improving physical studied soil parameters, rice crop, ETa and WUE. In addition, organic matter led to increase heat capacity soil air permeability by and decrease soil impedance whilst, water depletion show the very feeble effect, while the coupled with organic matter by mixing technique significantly effect on the all aforementioned studied parameters. Concern the root growth, it seems that root weight was affected significantly and directly by heat capacity and air permeability while the inverse significant correlation achieved with soil impedance. Cereal and rice straw yields show the significant directly correlation with organic manure and root weight while moisture depletion show a negative significant relation with cereal and negative non significant relation with straw, Whether, this may be due to that organic matter save the moisture and nutrients and big root absorb and supply the retentively water and nutrients to plant. Plant water consumption correlated by inverse significant with organic manure and root weight, while depletion show the non significant the later if it coupled with organic matter and root weight the significant was achieved. Also, WUE affected well by organic manure and root weight while depletion gives the inverse relation so the mixing technique was needed to perform to the highly significant correlation.

Based up on the antecede data we can summarized the following:

* Draught rice may be grown under draught condition reached 50\% moisture depletion but not grown well with high salt stress and alkali conditions of calcareous soil. However, Draught rice growth under and salinity stress will be great of attention in next work.

\section{REFERENCES}

Achmad R.; S.H. Anderson; G.J.G. and A.L. Thompson (2003). Influence of long term cropping system on soil physical properties related to soil erodibility. Soil, Sci.Soci. of America, J. 67: 637-644.

Adviento-Borbe, M.A.A., J.W. Doran; R.A. Drijber and A. Dobermann (2006). Soil electrical conductivity and water content affect nitrous oxide and carbon dioxide emissions in intensively managed soil. Journal environs Qual. 35: 1999-2010.

Akinremi, O.O.; S.M. Meginn and H.D.D. Mclean (1999). Effect of soil temperature and moisture on soil respiration in barely and fallow plots. Canadian, J. of soil Sci. V.79 No.1 PP.5-13.

Allen, R.G., L.S. Pereira, D. Raes and M. Smith. (1989). Crop evapotranspiration, guidelines for computing crop water requirements.Irrig.\& Drain. Paper, No. 56, FAO, Rom, Italy.

Amal, A.A. (1999). Studies on some Factors affecting heat capacity of some Egyptian desert soils. M S. C. Thesis faculty of science. Cairo University. Chemistry department.

Awadalla, S.Y.; M.A. Zayed; G.G. Mohamed and A.A. Amal (2001). Some factors affecting the heat capacity of sandy and calcareous soils. Desert Inst. Bull. Egypt, 51, No. 1 PP. 97-108.

Baver, L.D.; H.W. Gardner and R.W. Gardner (*1976). Soil Physics. 4thEd., First Wiley Eastern Reprint.

Begg, J.E. and Turner, N.C. 1976. Crops water deficits. Adv. Agron., 28:161

Cook, F.J. and Knight, J.H. (2003) Oxygen transport to plant roots: modeling for physical understanding of soil aeration. Soil Science Society of America Journal 67, 20-31.

Croser, C., Bengough, A.G. and Pritchard, J. (2000) The effect of mechanical impedance on root growth in pea (Pisum sativum). II. Cell expansion and wall rheology during recovery. Physiologia Plantarum 109, 150-159.

Daniel, G.; K. Anabayan; E. Bhman and W.D. John (2003). Green house gas emission and soil indicators four years after manure and compost application. Journal of environmental quality 32: 23-32.

El-Hadidi, E.M.; A.M. El-Ghamry and M.I. El. Amira (2002). Effect of soil amendements on physical properties in heavy clay soil in northern Nile delta. Egyptian soil science society $6^{\text {th }}$ Nat. congress, Oct. 29-30, (2002) Cairo. 
Farooq, M., Basra, S.M.A., Wahid, A., Cheema, Z.A., Cheema M.A. and Khaliq, A. 2008. Physiological role of exogenously applied glycinebetaine in improving drought tolerance of fine grain aromatic rice (Oryza sativa L.). $J$. Agron. Crop Sci., 194: 325-333

Giriappa, S. (1983). Water use efficiency in agriculture. Agricultural Development and Rural Transformation Unit. Institute for Social and Economic Change Bangalore. Oxford \& IBH Publishing Co.

Hiroko A. and Haruo (2003). Nitrous oxide, nitric oxide and nitrogen dioxide fluxes from soil after manure and urea application. Journal of Environmental Quality 32: 423-431. John J. H. and L.B. Wayne (1992). Soils and Their Environment. PP. 241-242. printed in the United States of Ameica.

Jack E. Rechcigle (1995). Soil Amendments and Environmental Quality. PP. 321

Jaleel, C.A., Manivannan, P., Lakshmanan, G.M.A., Gomathinayagam, M. and Panneerselvam, R. 2008c. Alterations in morphological parameters and photosynthetic pigment responses of Catharanthus roseus under soil water deficits. Colloids Surf. B: Biointerfaces, 61: 298-303

KANBAR, A., TOORCHI, M. and SHASHIDHAR H.E. (2009). Relationship between Root and Yield Morphological Characters in Rainfed Low Land Rice (Oryza sativa L.)Cereal Research Communications 37(2), pp. 261-268

Mohd, K., Mohd N., Ainun A., Md Sarwar J.(2015). Effect of various water regimes on rice production in lowland irrigation. AJCS 9(2):153-159.

Mumbani, B., Lal, R. (1983). Response of upland rice varieties to drought stress. II. Screening rice varieties by means of variable moisture regimes along a toposequence. Plant and Soil 73:73-94.

Munns R., Tester M. (2008): Mechanisms of salinity tolerance. Annual Review of Plant Biology, 59: 651-681.

Nidal, H.A. and C.R. Randall (2000). Soil thermal conductivity: effects of density, moisture, salts concentration, and organic matter. Soil Science Society Am. J. 64:1285-1290.

Swain, P., Mall, A.K., Bose, L.K., Baig, M.J. and Singh, D.N. 2010. Drought susceptibility index as a parameter to identify drought tolerant rice genotypes for rainfed uplands. In: Abs. National Symposium on Sustainable Rice Production System Under Changed Climate. CRRI, Cuttack, Orissa, India. 27-29 Nov. pp. 42.
Partington, J.R (1954). An Advanced treatise on physical chemistry.

Peter J. Gregory (2006) Plant Roots (Growth, Activity and Interaction with Soils). First published 2006 by Blackwell Publishing Ltd

Pirdashti H, Sarvestani ZT, Nematzadeh G, Ismail A (2004) Study of water stress effects in different growth stages on yield and yield components of different rice (Oryza sativa L.) cultivars. The 4th International Crop Science Congress. Brisbane, Australia

Richards,L.A.(Editor) (1954). Diagnosis And Improvement Of Saline And Alkaline Soils" U.S. Salinity Laboratory staff,Agriculture Handbook (60).

Richards, S.J.; R.M. Hagan and T.M. Mecalla (1952). Soil Physical Condition And Plant Growth. Shaw, B.T.(ed), ACADEMIC PRESS lnc. Pub. New York .

Russell, E.W. (1989). Soil Conditions and Plant Growth. ELBS edition of eleventh edition 1988, Reprinted 1989.

Seiler, G.J. (1998) Infl uence of temperature on primary and lateral root growth of sunfl ower seedlings. Environmental and Experimental Botany 40, 135-146.

Singh, A.K., Mall, A.K., Singh, P.K. and Verma, O.P. 2010. Interrelationship of genetics parameters for quantitative and physiological traits under irrigated and drought conditions. Oryza. 47(2): 142-147.

Soane, B.D. (1990). The Role of The Organic Matter On Soil Compactibility: A review of some particle aspects. Soil Tillage Res. 16; 179201.

Vandeleur RK, Mayo G, Shelden MC, Matthew Gilliham M, Kaiser BN, Tyerman SD (2009). The role of plasma membrane intrinsic protein aquaporins in water transport through roots: diurnal and drought stress responses reveal different strategies between isohydric and anisohydric cultivars of grapevine. Plant Physiol. 149:445-460.

Wagieh, A.A. El. (2002). A study on some management practices in calcareous soils and their reflection on soil physical, mechanical properties and crop production. M.S.C Thesis, Soil Sci. Department, faculty of agric. moshtohor Zagazig University (Banha Brannch).

Wang, H., Z. Wu, Y. Chen, C. Yang, D. Shi (2011). Effects of salt and alkali stresses on growth and ion balance in rice (Oryza sativa L.) PLANT SOIL ENVIRON. 57, (6): 286-294 


\section{الملخص العربى \\ الإدارة المائية والأرضية لأرز الجفاف \\ جيهان جمال عبد الغنى، مجدى حسن ذكى

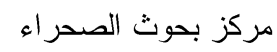

يعتبر الأرز من المحاصيل الإقتصادية واسعة الإستهلاك من قبل الإنسان، ويحقق انتاجية عالية تحت ظروف

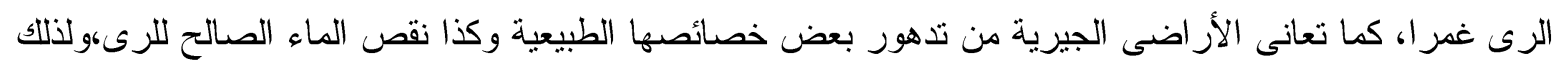
فإن ادارة الأرض والمياة عن طريق اضافة الاسمدة العضوية مع مستويات من الإستفاذ الرطوبى وارز الجفاف لإنى

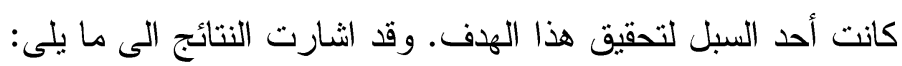

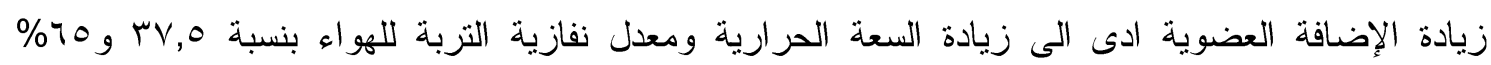

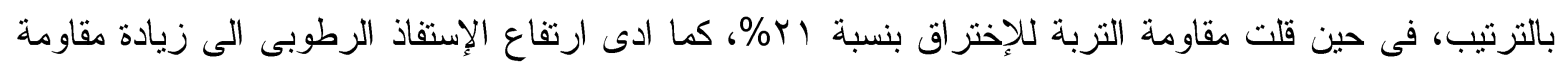

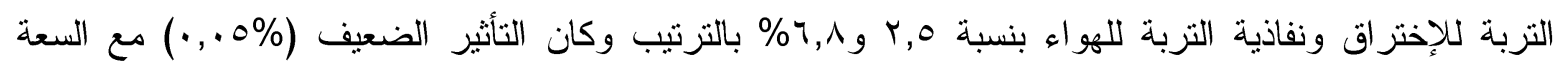

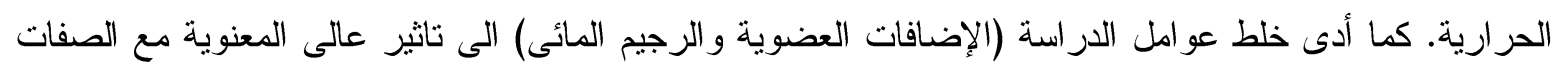
الطبيعية سالفة الذكر. ولوحظ ان تحسن هذه الصفات أدى الى زيادة فى وزن الجذور. كما ادى زيادة وزن الجذور والإضافة

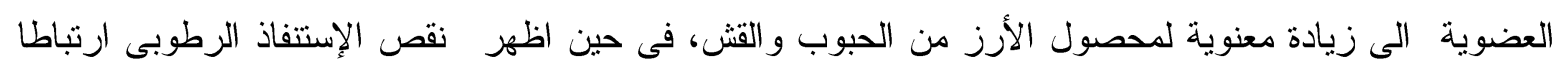

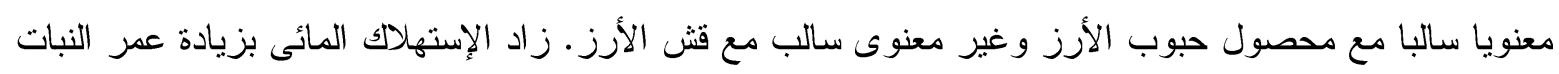

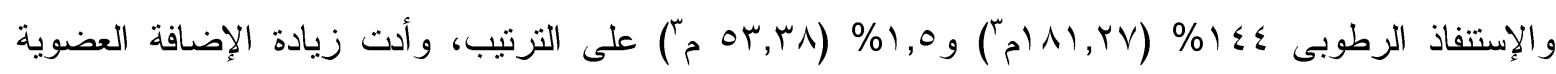

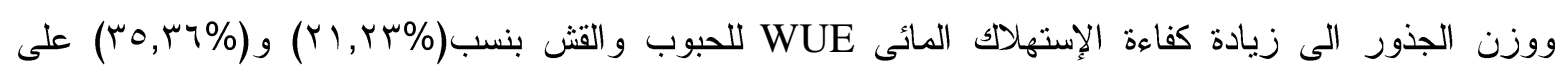
التزتيب فى حين إنخفضت بنسبة (؟ 9\%) و (7, 0 \%) للحبوب و القش على التو الى بزيادة الإستنفاذ الرطوبى. 